\title{
Thin layer spectroelectrochemical (RVC-OTTLE) studies of pertechnetate reduction in acidic media
}

\author{
M. Chotkowski • A. Czerwiński
}

Received: 22 July 2013/Published online: 16 February 2014

(C) The Author(s) 2014. This article is published with open access at Springerlink.com

\begin{abstract}
The electroreduction of the pertechnetate ions has been examined in sulfuric acid solutions $(0.5-4 \mathrm{M})$ using optically transparent thin layer spectroelectrochemical (RVC-OTTLE) cell. Soluble Tc(III), $\mathrm{TcO}^{2+}$ and [Tc $\left.(\mu-\mathrm{O})_{2} \mathrm{Tc}\right]^{3+/ 4+}$ species with absorption bands at $420-450$, 400 , and $502 \mathrm{~nm}$, respectively, were found to be formed during the reduction of $\mathrm{TcO}_{4}{ }^{-}$ions. The strongly acidic medium was found to stabilize technetium ionic forms with lower oxidation states. Spectroelectrochemical measurements performed in $4 \mathrm{M} \mathrm{H}_{2} \mathrm{SO}_{4}$ show different stability of dimeric structure of $\mathrm{Tc}(\mathrm{III}, \mathrm{IV})$ and simple $\mathrm{TcO}^{2+}$ ions. The monooxotechnetium(IV) ions can be electrooxidized at potentials lower than $0.6 \mathrm{~V}$ versus $\mathrm{Ag}, \mathrm{AgCl}_{\text {(sat.) }}$ while dimeric structures of $\mathrm{Tc},\left[\mathrm{Tc}(\mu-\mathrm{O})_{2} \mathrm{Tc}\right]^{3+/ 4+}$, are electrooxidized to pertechnetate ions at potentials higher than $0.8 \mathrm{~V}$ versus $\mathrm{Ag}, \mathrm{AgCl}_{\text {(sat.) }}$
\end{abstract}

Keywords Pertechnetate - Optically transparent thin layer electrodes

\section{Introduction}

Technetium-99 is one of nuclear fission products with a long half-life time $\left({ }^{99} \mathrm{Tc}: T_{1 / 2}=2.11 \times 10^{5}\right.$ years $)$ and a relatively high fission yield $(6 \%)$. Tc has a very high mobility in the environment [1]. This element is present at

Paper presented during the 6th All Polish Conference on Radiochemistry and Nuclear Chemistry, Krakow (Poland), 21-24.04.2013.

M. Chotkowski $(\bowtie) \cdot$ A. Czerwiński

Faculty of Chemistry, University of Warsaw, Pasteura 1, 02-093 Warsaw, Poland

e-mail: mchotk@chem.uw.edu.pl almost every stage of nuclear fuel reprocessing streams due to its high ability to be extracted with uranium by TBP (tri$n$-butyl phosphate) $[2,3]$. Technetium exists in a wide range of oxidation states, therefore, the spectroelectrochemistry is especially useful to study electrochemical and chemical processes with participation of Tc.

Generally, non-complexed technetium compounds can be ordered in the following series, according to their stability in the acidic media, Eq. (1):

$\mathrm{Tc}(\mathrm{VII})>\mathrm{Tc}(\mathrm{IV})>\mathrm{Tc}(\mathrm{III})>\mathrm{Tc}(\mathrm{VI})$

where $\mathrm{Tc}(\mathrm{VI})$ compounds are the most unstable ones. Recent studies [4] showed that only in extreme acidic media $\left(13 \mathrm{M} \mathrm{H}_{2} \mathrm{SO}_{4}\right)$ the reduction of pertechnetates can lead to formation of stable $\mathrm{TcO}^{3+}$ species. The UV-Vis spectrum of these species is characterized by the bands: the first one at $255 \mathrm{~nm}$ and the second one at $650-700 \mathrm{~nm}$, the last one with a small absorptivity $\left(\varepsilon=34 \mathrm{M}^{-1} \mathrm{~cm}^{-1}\right)$. A similar experiment performed in $6 \mathrm{M} \mathrm{H}_{2} \mathrm{SO}_{4}$ did not reveal formation of $\mathrm{Tc}(\mathrm{V})$ [4].

It was described in the literature that technetium(IV or III/IV) ionic species can exist in the acidic media in various forms, as e.g. dimeric structures of $\mathrm{Tc},\left[\mathrm{Tc}(\mu-\mathrm{O})_{2} \mathrm{Tc}\right]^{3+/ 4+}$ $[5,6]$ or polyoxopolymetallic $\mathrm{Tc}_{3} \mathrm{O}_{4}{ }^{4+}$ species [7]. These species can be characterized spectroscopically by a broad Vis band with a maximum absorption near $500 \mathrm{~nm}$. $\mathrm{TcO}^{2+}$ oxocations can be characterized spectroscopically by a band at $400 \mathrm{~nm}$ [8].

Despite mixed electrochemical and chemical pathways of pertechnetate ions reduction, the technetium compounds are good subjects for spectroelectrochemical studies $[9,10]$. However, only in a few cases the spectroelectrochemical studies were performed in aqueous solutions [11-13]. The experiments performed by Paquette and Lawrence [11] showed that in slightly basic media $(\mathrm{pH} 8)$ 
Tc(IV) and Tc(III) are stabilized by bicarbonates. These species were spectroscopically detected by weak bands in Vis range at 512 for Tc(IV), 470 and $630 \mathrm{~nm}$ for Tc(III). Thin layer spectroelectrochemical techniques have been also employed by Huber et al. [12] to study the behaviour of $\mathrm{TcCl}_{6}{ }^{2-}$ and $\mathrm{TcBr}_{6}{ }^{2-}$ in concentrated acidic media. Our previous study [13] performed in $0.5-4 \mathrm{M} \mathrm{H}_{2} \mathrm{SO}_{4}$ in a gold-optically transparent cell (Au-OTE) indicated that dimeric structures of $\mathrm{Tc}(\mathrm{III}, \mathrm{IV})$ are generated during electroreduction of pertechnetate ions.

The pertechnetate ions generate two absorption bands in the UV-Vis range: at 244 and $288 \mathrm{~nm}$ [14]. Therefore, the UV-Vis spectroscopy is especially suitable for studying the reactions involving these ions. The spectroelectrochemistry is particularly useful [9] for determining the mechanism of electrochemical reduction processes of technetium(VII). The working electrode is usually manufactured from an optically transparent material [10, 15], e.g. from RVC (Reticulated Vitreous Carbon), which was applied by Norwell and Mamantov [16] and Marassi et al. [17-19] in an optically transparent thin layer cell (OTTL-RVC cell). It has been demonstrated that for model systems, like o-tolidine or $\mathrm{K}_{3}\left[\mathrm{Fe}(\mathrm{CN})_{6}\right]$, the shape of $\mathrm{UV}-\mathrm{Vis}$ spectroscopic signal recorded in an optically transparent cell is similar to the shape of electrochemical voltammetric current versus potential $(j$ vs. $E$ ), curve $[9,15,17]$. The most convenient form of presentation of spectroscopic data recorded in OTTLEtype cells is a plot showing a time derivative of the absorbance $(\mathrm{d} A / \mathrm{d} t)$ as a function of the electrode potential. Such a plot, i.e. voltabsorbommogram, can be considered as an equivalent of simultaneously recorded current versus potential curve. However, such voltabsorbommogram can be calculated only for a single wavelength which has to be selected as the representative one for the analysed compound. Therefore, only one UVVis band is used for calculation of cyclic voltabsorbommograms although UV-Vis spectra can correspond to more than one electronic transition. The decrease of the absorbance for selected wavelength causes appearance of "negative" wave on cyclic voltabsorbommograns (for this wavelength).

The purpose of this work is to investigate the spectroelectrochemical behaviour of pertechnetate ions in 0.5-4 M sulphuric acid. It will be shown that the use of the OTTLE-RVC technique in conjunction with cyclic voltammetry allows for the determination of the mechanism related to the generation and stability of technetium species detected electrochemically on the electrode and spectroscopically in the solution.

\section{Experimental}

Spectroelectrochemical measurements were carried out in a home made optically transparent thin layer cell. A reticulated vitreous carbon-RVC (thickness $2 \mathrm{~mm}$; 100 ppi

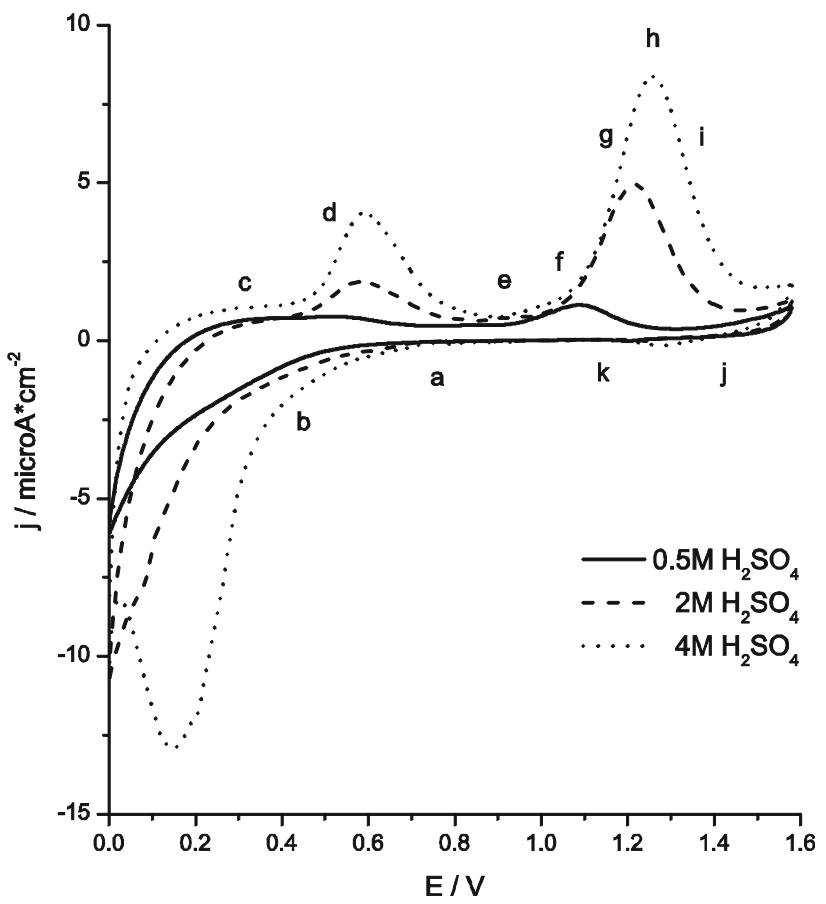

Fig. 1 Cyclic voltammograms recorded in $0.5 \mathrm{mM} \mathrm{KTcO} 4$ at various concentration of $\mathrm{H}_{2} \mathrm{SO}_{4}, v=2 \mathrm{mV} / \mathrm{s}, E_{\text {start }}=0.6 \mathrm{~V}$

porosity, ERG Aerospace Corporation) was used as a working electrode, and a platinized platinum gauze, as a counter electrode [20]. A saturated $\mathrm{Ag} / \mathrm{AgCl}$ electrode was used as a reference electrode, and all the potentials in the text are referred to this electrode.

All measurements were performed at $298 \mathrm{~K}$, the solutions were deoxygenated with $\operatorname{Ar}(4 \mathrm{~N})$. The solutions were prepared using high purity distilled water $\left(\right.$ Millipore $\left.{ }^{\circledR}\right)$ and high purity chemicals: potassium pertechnetate, $\mathrm{K}^{99} \mathrm{TcO} 4$ (obtained from Forschungszentrum Dresden-Rossendorf-Institute of Radiopharmacy) and $\mathrm{H}_{2} \mathrm{SO}_{4}$, (POCh, Poland). The electrochemical and spectroscopic measurements were performed simultaneously using CHI604 $(\mathrm{CH}$ Instruments) electrochemical analyzer and MultiSpec 1500 (Shimadzu) spectrophotometer, respectively.

\section{Results and discussion}

Figure 1 presents cyclic voltammograms recorded at scan rate of $2 \mathrm{mV} / \mathrm{s}$ for a RVC-OTTL electrode in $0.5,2$ and $4 \mathrm{M}$ $\mathrm{H}_{2} \mathrm{SO}_{4}$ with the addition of $0.5 \mathrm{mM} \mathrm{KTcO}_{4}$. The reduction of pertechnetate ions in $0.5 \mathrm{M} \mathrm{H}_{2} \mathrm{SO}_{4}$ results in a weak increase of cathodic current at potentials lower than $0.4 \mathrm{~V}$. According to the literature data [21] this electrochemical signal can be attributed to the electroreduction of pertechnetate ions to $\mathrm{TcO}_{2} \cdot x \mathrm{H}_{2} \mathrm{O}$ for solutions with $\mathrm{pH}$ greater than 3. Grassi et al. [22] postulated that electroreduction of 


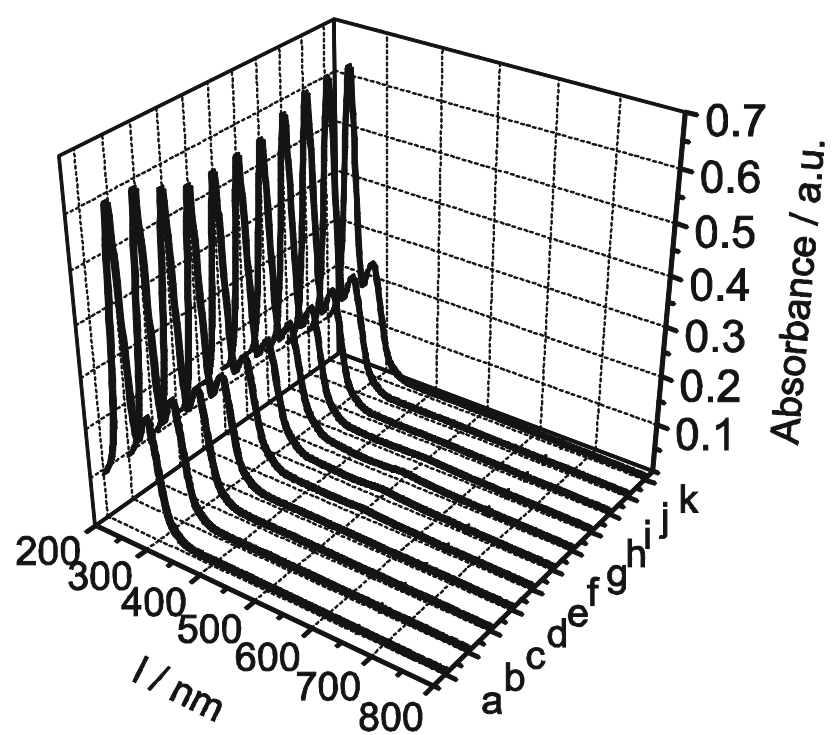

Fig. 2 UV-Vis spectra recorded during cyclic voltammogram experiment in $0.5 \mathrm{mM} \mathrm{KTcO}_{4}+0.5 \mathrm{M} \mathrm{H}_{2} \mathrm{SO}_{4}$

pertechnetate ions in $\mathrm{H}_{2} \mathrm{SO}_{4}$ with the concentration as high as $0.5 \mathrm{M} \mathrm{H}_{2} \mathrm{SO}_{4}$ generates not only $\mathrm{Tc}(\mathrm{IV})$ but also $\mathrm{Tc}(\mathrm{III})$ species. Other reports [5] indicated $\mathrm{Tc}_{n} \mathrm{O}_{y}^{(4 n-2 y)+}$ polymeric species as the product of pertechnetates electroreduction. Also Maslennikov et al. [23] reported that $\mathrm{Tc}(\mathrm{VII})$ can be reduced to $\mathrm{Tc}(\mathrm{III})$ species in nitric acid solutions. Vichot et al. [7] suggested that the discussed process can be accompanied by synproportionation of electrogenerated $\mathrm{Tc}(\mathrm{III})$ species and $\mathrm{Tc}(\mathrm{VII})$ ions to $\mathrm{Tc}(\mathrm{IV})$. In more concentrated sulfuric acid solutions, the electoreduction wave is better developed which suggests changes both in the mechanism of $\mathrm{TcO}_{4}{ }^{-}$ions electroreduction and in composition of the resulting products.

Presence of two anodic waves observed on cyclic voltammograms at potentials of 0.4 and $0.9-1 \mathrm{~V}$ indicates that pathways of electrooxidation of low valence technetium species to $\mathrm{TcO}_{4}{ }^{-}$cannot be treated as a process composed with the same steps as electroreduction of pertechnetate ions and appearing in a reversed order. The results presented in this work and in our previous paper [13] devoted to studied on electrochemistry of pertechnetates with the use of gold electrodes in the same concentrations of sulphuric acid solutions strongly indicate that electrooxidation of $\mathrm{Tc}(\mathrm{III})$ species to $\mathrm{Tc}(\mathrm{IV})$ is not the only one process that contributes to formation of the broad and poor shaped first anodic wave observed in the potential range of $0.2-0.6 \mathrm{~V}$. Thus, an additional electrochemical process, e.g. electrooxidation of $\mathrm{Tc}(\mathrm{IV})$ to $\mathrm{Tc}(\mathrm{VII})$ species, must occur in the same potential region. According to the literature [24] the $\mathrm{Tc}(\mathrm{III})$ species are very prone to oxidation to $\mathrm{Tc}(\mathrm{IV})$. The second anodic wave appears at much higher potentials $(0.8-1.2 \mathrm{~V})$. At such high potentials other Tc(III, IV)

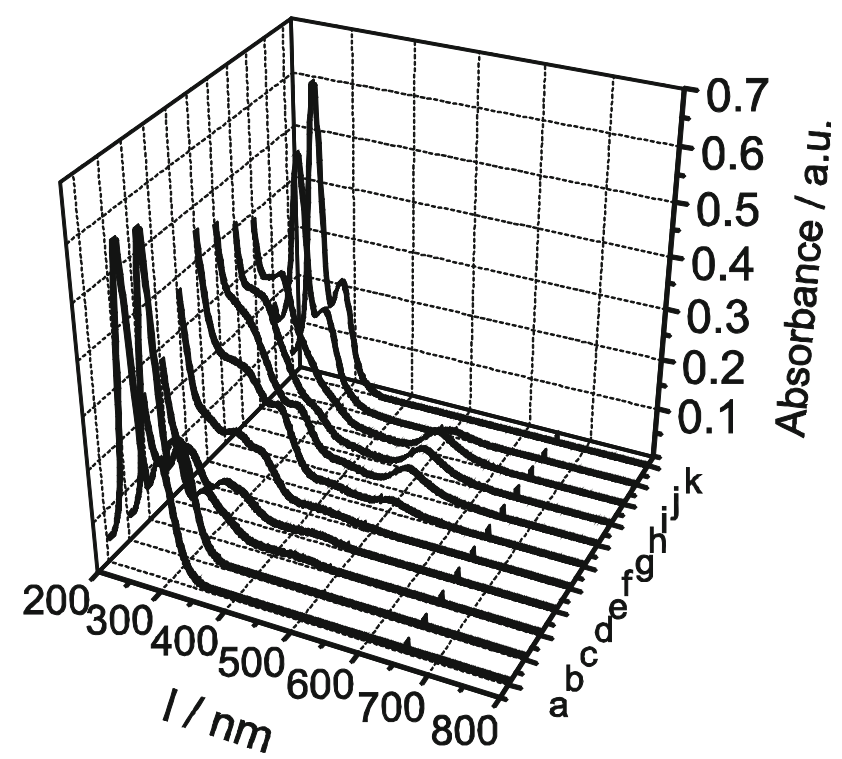

Fig. 3 UV-Vis spectra recorded during cyclic voltammogram experiment in $0.5 \mathrm{mM} \mathrm{KTcO}_{4}+4 \mathrm{M} \mathrm{H}_{2} \mathrm{SO}_{4}$

species are electrooxidised to pertechnetate ions as it will be described later.

To confirm the conclusion on the electrochemical behaviour of technetium species in the acidic media, the spectroscopic signals were recorded simultaneously with the cyclic voltammograms. Figure 2 presents the UV-Vis spectra recorded during cyclic voltammetry of pertechnetate ions in $0.5 \mathrm{M} \mathrm{H}_{2} \mathrm{SO}_{4}$. No significant decrease of the $\mathrm{TcO}_{4}{ }^{-}$ions concentration is observed for this acid concentration, as follows from an analysis of absorption bands at 244 and $288 \mathrm{~nm}$. The obtained results are consistent with simultaneously recorded electrochemical data where only small noise current is recorded. For this acid concentration the discussed process is electrochemically irreversible on the carbon electrodes.

Totally different UV-Vis spectra are observed during the electroreduction of pertechnetate ions in much more concentrated acidic solutions (Fig. 3). In $4 \mathrm{M} \mathrm{H}_{2} \mathrm{SO}_{4}$, the technetium species with oxidation states lower than +VII are observed. The spectra reveal formation of a weak wave with a maximum in the range of $420-450 \mathrm{~nm}$ in the first step of the discussed process. At the same time a significant decrease of the concentration of the pertechnetate ions $\left(\lambda_{\max }=244,288 \mathrm{~nm}\right)$ is observed. For Mn(III) ions in the sulfuric acid solutions [20] a band with a maximum at $476 \mathrm{~nm}$ is observed. Generally, despite that the fact that the technetium is located in the same as the manganese group of periodic table, the absorption band for Tc should be shifted to a shorter wavelength as compared to Mn with the same ionic form and in the same medium [25]. Technetium(III) in his high spin aqueous complex, $\mathrm{Tc}\left(\mathrm{H}_{2} \mathrm{O}\right)_{6}^{3+}$, 

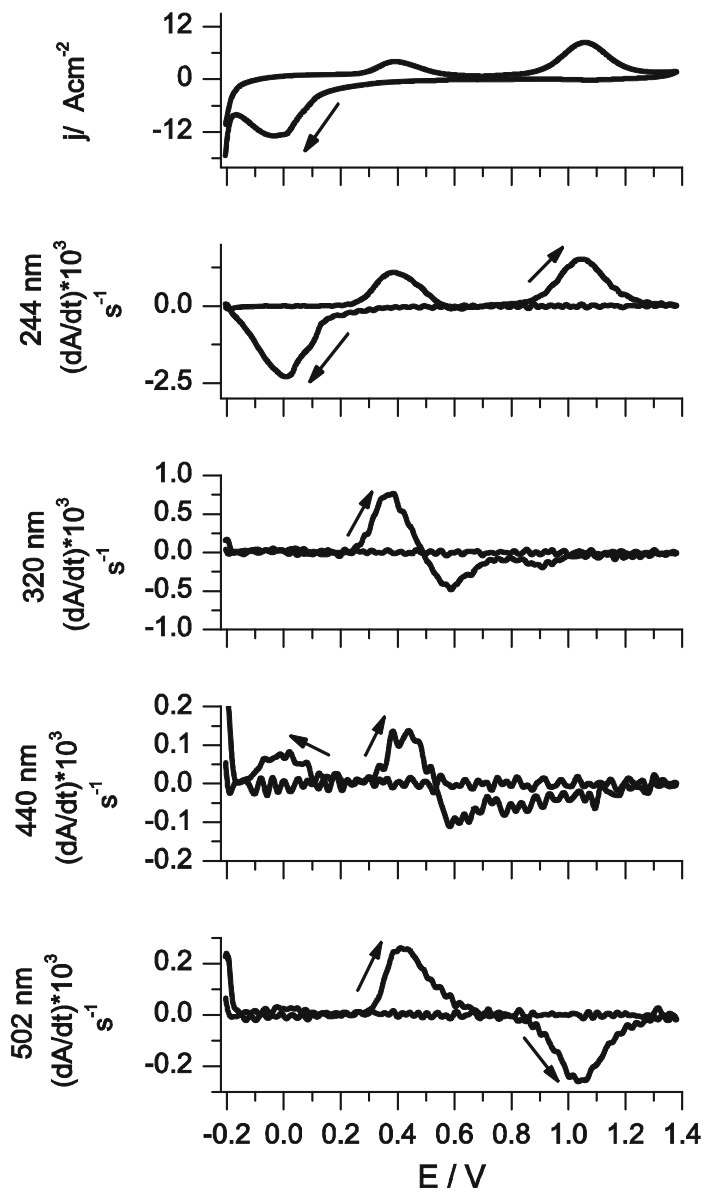

Fig. 4 Cyclic voltammograms and voltabsorbommograms for wavelengths $244,320,440$ and $504 \mathrm{~nm}$ of a OTTL-RVC electrode in $4 \mathrm{M}$ $\mathrm{H}_{2} \mathrm{SO}_{4}+0.5 \mathrm{mM} \mathrm{KTcO}_{4}, \mathrm{v}=1 \mathrm{~m} \mathrm{~V} / \mathrm{s}, E_{\text {start }}=0.6 \mathrm{~V}$

should have $[\mathrm{Kr}] 4 \mathrm{~d}^{4}$ electronic configuration and from this reason the $\mathrm{d}-\mathrm{d}$ transition should be allowed and respective bands in UV-Vis spectra should be observed. Such tendency has been observed in our experimental cell. The obtained results suggest that the wave with the maximum near $440 \mathrm{~nm}$ can be attributed to a technetium (III) ionic form. At higher potentials $(0.7 \mathrm{~V}$, see: $\mathrm{UV}-\mathrm{V}$ is spectrum for point "e" in Fig. 3) the observed wave shifts to shorter wavelengths. Based on the literature data [8] we suggest that this behaviour can indicate generation of soluble $\mathrm{TcO}^{2+}$ ions. At potentials higher than $0.8 \mathrm{~V}$ a band with a maximum at $502 \mathrm{~nm}$ is recorded. This band indicates that during the electrooxidation of the technetium with oxidation states lower than +IV the dimeric structures of Tc(III, IV) are generated.

Figure 4 presents a cyclic voltammogram recorded at scan rate of $1 \mathrm{mV} / \mathrm{s}$ and cyclic voltabsorbommograms calculated for the same scan rate for $244\left(\mathrm{TcO}_{4}{ }^{-}\right), 320$ $(\mathrm{Tc}(\mathrm{IV})), 440(\mathrm{Tc}(\mathrm{III}))$, and $502\left(\left[\mathrm{Tc}(\mu-\mathrm{O})_{2} \mathrm{Tc}\right]^{3+/ 4+}\right) \mathrm{nm}$ for a RVC-OTTL electrode in $4 \mathrm{M} \mathrm{H}_{2} \mathrm{SO}_{4}$. Electroreduction of pertechnetate ions in acidic media leads to

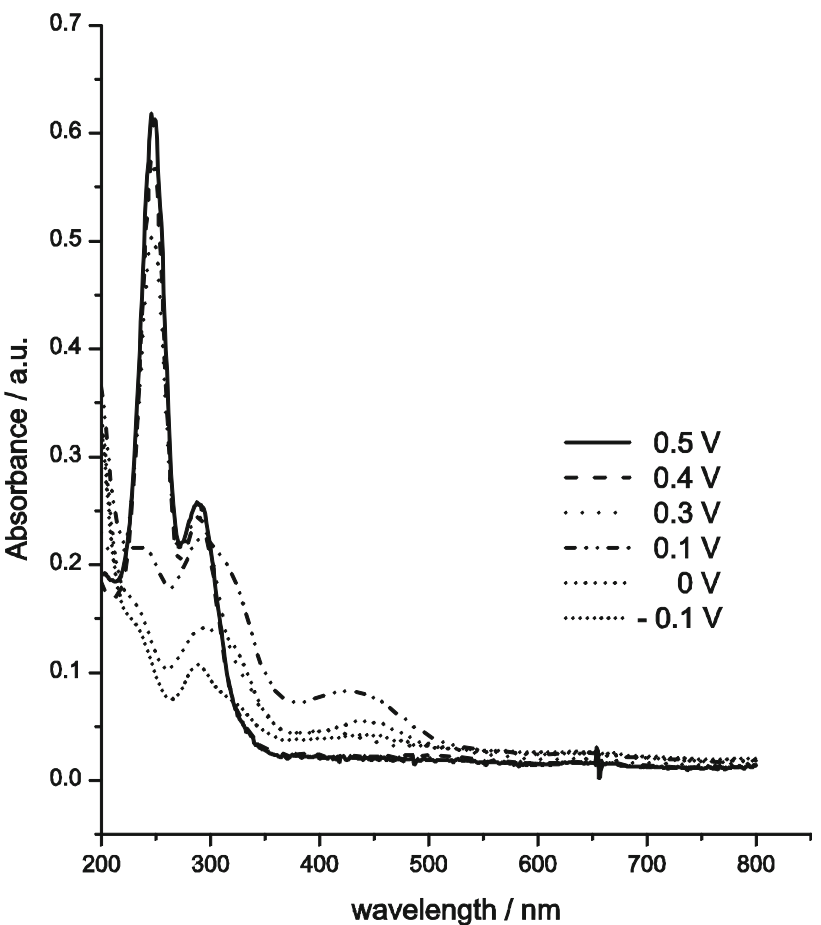

Fig. 5 UV-Vis spectra recorded during chronoamperometric experiment in $0.5 \mathrm{mM} \mathrm{KTcO}_{4}+4 \mathrm{M} \mathrm{H}_{2} \mathrm{SO}_{4}$. Applied potential program (1 min. for each step): $0.5 \mathrm{~V} \rightarrow 1.1 \mathrm{~V} \rightarrow 0.4 \mathrm{~V} \rightarrow 1.1 \mathrm{~V} \rightarrow$ $0.3 \mathrm{~V} \rightarrow 1.1 \mathrm{~V} \rightarrow 0.1 \mathrm{~V} \rightarrow 1.1 \mathrm{~V} \rightarrow 0 \mathrm{~V} \rightarrow 1.1 \mathrm{~V} \rightarrow-0.1 \mathrm{~V}$

formation of $\mathrm{Tc}(\mathrm{III})$ species, probably in the form of $\mathrm{Tc}^{3+}$ or $\mathrm{TcO}^{+}$. These species are responsible for formation of a positive" wave observed at potentials lower than $0.2 \mathrm{~V}$ on voltabsorbommogram calculated for the wavelength of $440 \mathrm{~nm}$. No waves characteristic for technetium(III,IV) are observed in the same potentials range. One may suggest that these observations indicate generation of technetium(III) ionic forms as major products of perechnetate ions electroreduction in strongly acidic media. However, it is quite likely that before or after the generation of $\mathrm{Tc}(\mathrm{III})$ ions also other technetium species with higher than +III oxidation states are generated.

An anodic wave observed at cyclic voltammograms at potentials higher than $0.2 \mathrm{~V}$ is attributed to the electrooxidation of $\mathrm{TcO}^{+}$or $\mathrm{Tc}^{3+}$ ions to technetium(III,IV) soluble species, e.g. $\left[\mathrm{Tc}(\mu-\mathrm{O})_{2} \mathrm{Tc}\right]^{3+/ 4+}$. At these potentials a positive wave on voltabsorbommogram calculated for $502 \mathrm{~nm}$ ) appears. These species are later electrooxidized to pertechnatate ions at relatively high potentials (higher than $0.9 \mathrm{~V})$.

The band at $320 \mathrm{~nm}$ corresponds to a molecular electronic transition of polymeric Tc(IV) species [5]. For this wavelength the negative wave appears at much lower potentials (start at $0.5 \mathrm{~V}$ ) than for dimeric structure of Tc(III, IV) (start at $0.8 \mathrm{~V}$ ). This observation suggests that the wave at $320 \mathrm{~nm}$ is related not to dimeric structure of 


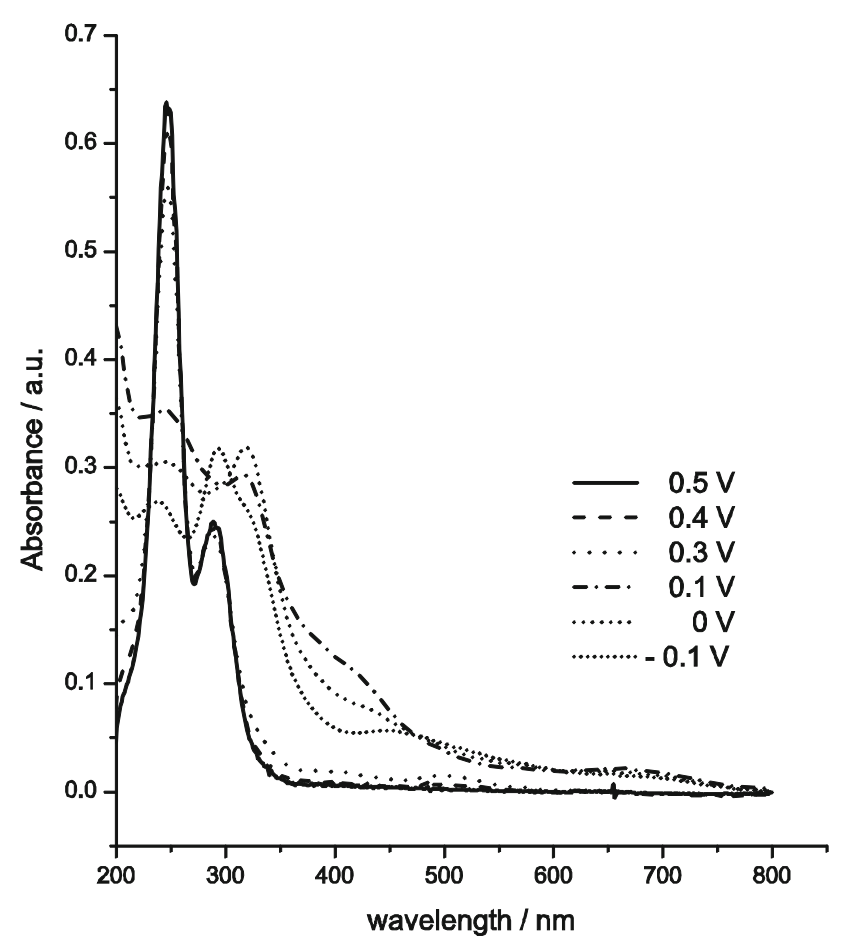

Fig. 6 UV-Vis spectra recorded during chronoamperometric experiment in $0.5 \mathrm{mM} \cdot \mathrm{KTcO}_{4}+4 \mathrm{M} \cdot \mathrm{H}_{2} \mathrm{SO}_{4}$. Applied potential program (1 min. for each step): $0.5 \mathrm{~V} \rightarrow 0.4 \mathrm{~V} \rightarrow 0.3 \mathrm{~V} \rightarrow 0.1 \mathrm{~V} \rightarrow 0 \mathrm{~V} \rightarrow$ $-0.1 \mathrm{~V}$

Tc(III, IV) but should be linked with other Tc(IV) species. $\left[\mathrm{Tc}(\mu-\mathrm{O})_{2} \mathrm{Tc}\right]^{3+/ 4+}$ species generate much more intense negative wave at potentials higher than $0.8 \mathrm{~V}$. Observed decrease of the absorbance at $502 \mathrm{~nm}$ (what is related with the "negative" wave on cyclic voltabsommograms) at potentials higher than $0.8 \mathrm{~V}$ indicates electrooxidation of these ions to $\mathrm{TcO}_{4}{ }^{-}$. Generation of pertechnetate ions in discussed range of potentials leads to an increase in the intensities of $\mathrm{TcO}_{4}{ }^{-}$characteristic band $(244 \mathrm{~nm})$ and "positive" waves on cyclic voltabsorbommograms (at 0.4 and $1.0 \mathrm{~V}$ ). In fact, the absorbance band at $320 \mathrm{~nm}$ attributed to Tc(IV) species should also increase simultaneously but this wavelength can be also attributed to $\mathrm{Tc}(\mathrm{VII})$ species. Therefore, a weak spectroscopic $(0.8-1.0 \mathrm{~V})$ signal is detected as a result of a superposition of waves for $\mathrm{TcO}_{4}{ }^{-}$and $\mathrm{Tc}(\mathrm{IV})$.

Figures 5 and 6 present UV-Vis spectra recorded during chronoamperometric reduction of pertechnetate ions in $4 \mathrm{M} \mathrm{H}_{2} \mathrm{SO}_{4}$. Two procedures were applied:

- In the first procedure the potential was changed between fixed upper limit of $1.1 \mathrm{~V}$ and various lower limits in the range from 0.5 to $-0.1 \mathrm{~V}$ with $0.1 \mathrm{~V}$ steps and with duration of 1 min., i.e. $0.5 \mathrm{~V} \rightarrow 1.1 \mathrm{~V} \rightarrow 0.4 \mathrm{~V} \rightarrow$ $1.1 \mathrm{~V} \rightarrow 0.3 \mathrm{~V} \rightarrow 1.1 \mathrm{~V} \rightarrow$ etc. ("direct" electroreduction of $\mathrm{TcO}_{4}{ }^{-}$, Fig. 5).
- The second procedure utilised stepwise changes of potential in cathodic direction with $0.1 \mathrm{~V}$ steps with duration of 1 min., i.e. $0.5 \mathrm{~V} \rightarrow 0.4 \mathrm{~V} \rightarrow 0.3 \mathrm{~V} \rightarrow$ etc. (Fig. 6).

A comparison of Figs. 5 and 6 indicates that for the same value of reduction potential (e.g. $300 \mathrm{mV}$ for both Figs. 5, 6) different reduced Tc species are generated in both procedures. "Direct" electroreduction of $\mathrm{TcO}_{4}{ }^{-}$ (Fig. 5) leads to generation of soluble technetium species characterised spectroscopically by the band at $440 \mathrm{~nm}$. Stepwise electroreduction of pertechnetate ions in the second procedure leads to formation of bands at 320 and $248 \mathrm{~nm}$ which indicate existence of soluble structures of $\mathrm{Tc}(\mathrm{IV})$ and $\mathrm{TcO}_{4}{ }^{-}$. A similar UV-Vis spectrum (obtained in the solution with $\mathrm{pH} 0$ was interpreted by Vongsouthi et al. [5] as a result of formation of a mixture of $20 \%$ $\mathrm{TcO}_{4}{ }^{-}$and $40 \% \mathrm{Tc}(\mathrm{IV}$, dimer) species. Further electroreduction of these species (Fig. $6, E=0.3 \mathrm{~V}$ ) leads to formation of technetium species characterised spectroscopically by bands at 244,288 and $440 \mathrm{~nm}$, characteristic for pertechnetate ions and for postulated by us Tc(III) soluble species. Our results are partially inconsistent with the results reported by Vongsouthi et al. [5] which indicated that Tc(III) species should not be detected spectroscopically in UV-Vis range. However, the acidity of the solutions used in our experiments $\left(4 \mathrm{M} \cdot \mathrm{H}_{2} \mathrm{SO}_{4}\right)$ was much higher than in experiments performed by Vongsouthi et al. $(\mathrm{pH} 0)$ and this factor may influence the solubility of $\mathrm{Tc}(\mathrm{III})$ species. According to the recent literature data [4], formation of technetium (V) during the electroreduction of pertechnetate ions should be considered (Fig. 6, $\mathrm{E}=0.1 \mathrm{~V}$ ). At this value of potential a weak wave with the maximum centred at $650-700 \mathrm{~nm}$ is observed on UVVis spectrum. Poineau et al. [4] indicated that the molar absorption coefficient for technetium(V) for this band is low $\left(\varepsilon=34 \mathrm{M}^{-1} \mathrm{~cm}^{-1}\right)$. It is also puzzling that they reported generation of $\mathrm{TcO}^{3+}$ only in $13 \mathrm{M} \mathrm{H}_{2} \mathrm{SO}_{4}$ and not in $6 \mathrm{M} \mathrm{H}_{2} \mathrm{SO}_{4}$. In our experiments concentration of sulphuric acid was even lower $\left(4 \mathrm{M} \mathrm{H}_{2} \mathrm{SO}_{4}\right)$. From this reason it is also possible that the absorbance increase observed at $600-700 \mathrm{~nm}$ could be linked to hydrated technetium(III) oxohydroxides(?).

An additional chronoamperometric experiments were applied to determine the stability of selected technetium species in $4 \mathrm{M} \mathrm{H}_{2} \mathrm{SO}_{4}$. In Fig. 7 are presented spectra recorded during and after reduction of $\mathrm{TcO}_{4}{ }^{-}$at applied potentials of 0 and $0.5 \mathrm{~V}$ and under open circuit conditions. At potential of $0 \mathrm{~V}$ the technetium(III) and (IV) forms are generated. The wave characteristic for $\mathrm{TcO}^{2+}$ with the maximum at $400 \mathrm{~nm}$ is misshapen due to overlapping with the wave characteristic for Tc(III) ions. Additionally, a weak shoulder at $500 \mathrm{~nm}$ indicates the appearance of 


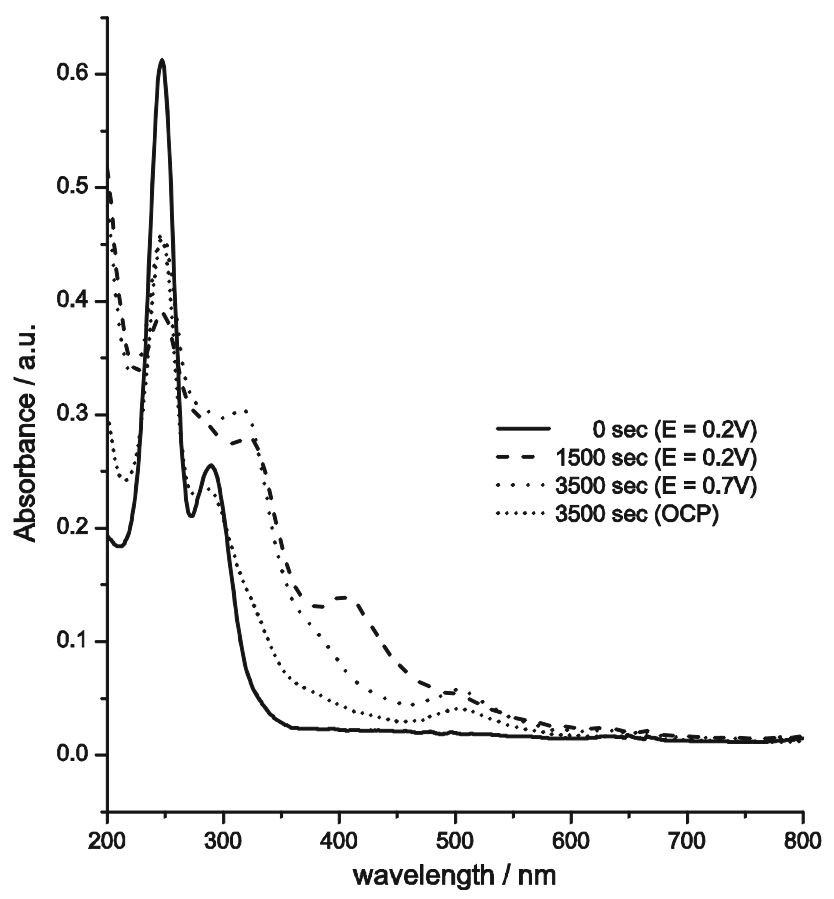

Fig. 7 UV-Vis spectra recorded during chronoamperometric experiment and after them (at open circuit potential) in $0.5 \mathrm{mM}$ $\mathrm{KTcO}_{4}+4 \mathrm{M} \mathrm{H}_{2} \mathrm{SO}_{4}$

$\left[\mathrm{Tc}(\mu-\mathrm{O})_{2} \mathrm{Tc}\right]^{3+/ 4+}$ ions in the solution. At $0.5 \mathrm{~V}$, a significant decrease of the absorbance in the UV-Vis range (from 370 to $470 \mathrm{~nm}$ ) and an increase of the absorbance at $248 \mathrm{~nm}$ are observed. Such behaviour indicates that at this potential $\mathrm{TcO}^{2+}$ and $\mathrm{Tc}(\mathrm{III})$ forms are electrooxidized to pertechnetate ions. After 2,500 s at open circuit potentials, the dimeric structures of technetium(IV) are still present in the solution. However, at open circuit the intensity of the wave connected with these forms decreased about twice in comparison to conditions when the electrode was polarized at potential $0.5 \mathrm{~V}$.

\section{Conclusions}

During the electroreduction of pertechnetate ions in acidic media the technetium soluble species with + III and + IV oxidation states are generated. The spectroelectrochemical thin layer technique allowed the identification of particular technetium forms. Tc(III) ions can be spectroscopically characterized by the band with the maximum near $440 \mathrm{~nm}$. These species can be easy oxidized to technetium(IV) existing in the solution as simple $\mathrm{TcO}^{2+}$ ions and dimeric forms of $\mathrm{Tc}(\mathrm{III}, \mathrm{IV}),\left[\mathrm{Tc}(\mu-\mathrm{O})_{2} \mathrm{Tc}\right]^{3+/ 4+}$. Chronoamperometric experiments clearly show that monooxotechnetium(IV) ions are much easier oxidized to pertechnetate ions than dimeric structures of Tc(III,IV).
Acknowledgments This work was financially supported by Faculty of Chemistry, University of Warsaw, (501/86 DSM 102400). The authors would like to thank Dr. Hans Pietzsch from Forschungszentrum Dresden-Rossendorf (Institute of Radiopharmacy) and Prof. Jerzy Ostyk-Narbutt from Institute of Nuclear Chemistry and Technology in Warsaw for providing potassium pertechnetate.

Open Access This article is distributed under the terms of the Creative Commons Attribution License which permits any use, distribution, and reproduction in any medium, provided the original author(s) and the source are credited.

\section{References}

1. Hu Q (2010) In: Atwood DA (ed) Radionuclides in the environment. Wiley, New York

2. Loveland WD, Morrissey DJ, Seaborg GT (2006) Modern nuclear chemistry. Wiley, New York, pp 1-28

3. Hu Q-H, Weng J-Q, Wang J-S (2010) J Environ Radioact 101:426-437

4. Poineau F, Weck PF, Burton-Pye BP, Denden I, Kim E, Kerlin W, German KE, Fattahi M, Francesconi LC, Sattelberger AP, Czerwinski KR (2013) Dalton Trans 42:4348-4352

5. Vongsouthi N, Fattahi M, Grambow B (2006-2008) Subatech UMR 6457 Laboratoire de Physique Subatomique et des Technologies Associées, Scientific Report http://www-subatech.in2p3. fr/Documents/SUBATECH2009.pdf

6. Mausolf E, Poineau F, Droessler J, Czerwinski KR (2011) J Radioanal Nucl Chem 288(3):723-728

7. Vichot L, Fattahi M, Musikas C, Grambow B (2003) Radiochim Acta 91:263-271

8. Tumanova DN, German KE, Peretrukhin VF, Yu Tsivadze (2008) A Dokl Phys Chem 420:114-117

9. Heineman WR, Hawkridge FM, Blount HN (1984) Electroanalytical chemistry. Marcel Deker, New York

10. Hurst RW, Heineman WR, Deutsch E (1981) Inorg Chem 20:3298-3303

11. Paquette J, Lawrence WE (1985) Can J Chem 63:2369-2373

12. Huber EW, Heineman WR, Deutsch E (1987) Inorg Chem 26(22):3718-3722

13. Chotkowski M, Czerwiński A (2012) Electrochim Acta 76:165-173

14. Rulfs L, Pacer RA (1967) Hirsch RF 29:681-691

15. Bancroft EE, Sidwell JS, Blount HN (1981) Anal Chem 53:1390-1394

16. Norwell VE, Mamantov G (1977) Anal Chem 49(9):1470-1472

17. Zamponi S, Czerwiński A, Gambini G, Marassi R (1992) J Electroanal Chem 332:63-71

18. Zamponi S, DiMarino M, Czerwiński A, Marassi R (1988) J Electroanal Chem 248:341-348

19. Zamponi S, Czerwiński A, Marassi R (1989) J Electroanal Chem 266:37-46

20. Chotkowski M, Rogulski Z, Czerwiński A (2011) J Electroanal Chem 651:237-242

21. Lawson BL, Scheifers SM, Pinkerton TC (1984) J Electroanal Chem 177:167-181

22. Grassi J, Devynck J, Trèmillon B (1979) Anal Chim Acta 107:47-58

23. Maslennikov AG, Courson O, Perettroukhine VE, David F, Masson M (1997) Radiochim Acta 78(1):123-129

24. Rard JA (ed) (1999) Chemical thermodynamics of technetium. Elsevier, New York

25. Kettle SFA (1996) Physical inorganic chemistry. In: Langmuir M (ed) A coordination chemistry approach. Oxford University Press, Oxford 